\begin{tabular}{|c|l|}
\hline Title & NF membrane fouling by al uminum and iron coagul ant residuals after coagul ation-MF pretreatment \\
\hline Author(s) & $\begin{array}{l}\text { Ohno, Koichi; Matsui, Y oshihiko; Itoh, Masaki; Oguchi, Y oshifumi; Kondo, Takuya; Konno, Y osuke; Matsushita, } \\
\text { Taku; Magara, Y asumoto }\end{array}$ \\
\hline Citation & $\begin{array}{l}\text { Desalination, 254(1-3), 17-22 } \\
\text { https://doi.org/10.1016/.desal.2009.12.020 }\end{array}$ \\
\hline Issue Date & 2010-05-15 \\
\hline Doc URL & http://hdl.handle.net/2115/42974 \\
\hline Type & article(author version) \\
\hline File Information & Des2541-3_17-22.pdf \\
\hline
\end{tabular}

Instructions for use 


\title{
NF membrane fouling by aluminum and iron coagulant residuals after coagulation-MF pretreatment
}

Koichi Ohno a*, Yoshihiko Matsui ${ }^{a}$, Masaki Itoh ${ }^{\mathrm{b}}$, Yoshifumi Oguchi ${ }^{\mathrm{a}}$, Takuya Kondoa, Yosuke Konno ${ }^{\text {, Taku Matsushita }}{ }^{\text {a }}$, Yasumoto Magara ${ }^{\mathrm{c}}$

a Graduate School of Engineering, Hokkaido University, N13W8, Sapporo 060-8628, Japan; Tel. \& Fax +81 (11) 706-7282; emails: ohnok@eng.hokudai.ac.jp (K. Ohno), matsui@eng.hokudai.ac.jp (Y. Matsui),taku-m@eng.hokudai.ac.jp (T. Matsushita) ${ }^{b}$ Department of Water Supply Engineering, National Institute of Public Health, Saitama, Japan; Tel. +81 (48) 458-6298; Fax+81 (48)458-6299; email: itoh@niph.go.jp c Center for Environmental Nano and Bio Engineering, Hokkaido University, Sapporo, Japan; Tel. \& Fax +81 (11) 706-7278; email: magara@eng.hokudai.ac.jp

${ }^{*}$ Corresponding author

\begin{abstract}
The effects of coagulant residuals on fouling of a nanofiltration (NF) membrane were investigated. Experiments were carried out with a laboratory-scale microfiltration (MF)-NF setup and a pilot MF-NF plant. In the laboratory-scale experiments, NF feed water was pretreated with poly-aluminum chloride ( $\mathrm{PACl}$ ) or alum followed by $\mathrm{MF}$. NF membrane permeability declined when the feed water contained residual aluminum at $18 \mu \mathrm{g} / \mathrm{L}$ or more, but not when it was lower than $9 \mu \mathrm{g} / \mathrm{L}$. When pretreated with ferric chloride, no substantial decline of NF membrane permeability was observed; residual iron did not affect the permeability. When $\mathrm{SiO}_{2}$ was added to the water before the pretreatment with $\mathrm{PACl}$, the NF membrane permeability declined at about double the speed. Thermodynamic calculations and elemental analysis of foulants recovered from the membranes indicated that the majority of inorganic foulants were compounds composed of aluminum, silicate, and possibly potassium. In the pilot plant, NF feed was pretreated by PACl. Transmembrane pressure for NF doubled over 4.5 months of operation. Although the aluminum concentration in the NF feed was not high $(30 \mu \mathrm{g} / \mathrm{L})$, analysis of membrane foulants revealed excessive accumulation of aluminum and silicate, also suggesting that aluminum residuals caused the membrane fouling by alumino-silicates or aluminum hydroxide.
\end{abstract}


Keywords: Nanofiltration; Microfiltration; Poly-aluminum chloride; Ceramic membrane; Silicate; Potassium

\section{Introduction}

Nanofiltration (NF) is a promising advanced drinking water treatment process that offers an efficient alternative to conventional advanced treatment (ozone-activated carbon) and has the potential to produce potable water of better quality. Although NF is expected to perform better than conventional advanced treatment in removing natural organic matter, precursors of disinfection by-products $[1,2]$ and trace hazardous chemicals such as pesticides [3] from water; however, NF is still more expensive, and its cost needs to be reduced if it is to be widely accepted.

Membrane fouling leads to a continuous decline in membrane permeability, and fouling mitigation considerably reduces the cost of designing and operating membrane filtration systems. In the case of NF of surface waters, the accumulation of particulate matter severely decreases the permeability of the NF membranes; such particulates must be removed by pretreatment processes such as coagulation, followed by clarification and then multi-media filtration or microfiltration (MF).

Although these pretreatments can alleviate the effect of organic foulants as well as that of particulate, the pretreatment increases coagulant residuals to NF feed and they may precipitate on the membrane surface and reduce membrane permeability. Kim et al. [4] used three types of NF feed: untreated raw water (RAW water), pretreated by in-line coagulation followed by MF (MF water) and pretreated by coagulation, sedimentation and sand filtration (CS water). They found that the order of the ratio of inorganic foulants to the total amounts of foulants was CS water $>$ MF water $>$ RAW water. Gabelich et al. tested reverse osmosis (RO) membrane using feed pretreated with conventional or direct filtration treatment plants. They used either alum or ferric chloride, and also used cationic polymer and chloramines for pretreatment. The tests using alum with $\mathrm{RO}$ elements revealed rapid deterioration in specific flux, on the other hand, the specific flux using ferric chloride did not decrease over time [5]. They also suggested that three types of aluminum-based foulants: aluminum silicates, aluminum hydroxides, and aluminum phosphates [6]. Accordingly, both pretreatment methods and types of coagulants may play a crucial role in the control of NF/RO fouling. Application of conventional coagulation, clarification and multi-media filtration can take advantage of preexisting facilities; however, the processes offset the benefit of small area required for NF membrane process. Pre-coagulated MF would be more advantageous process for 
pretreatment for NF.

Most of the surface water treatment plants in Japan that have coagulation process currently use aluminum coagulants [7]. During our pilot plant experiment [8], which is also discussed in this study, we found that residual aluminum coagulants in the NF feed might cause the membrane fouling. Therefore, the objective of this study was to investigate the effects of coagulant residuals on NF membrane fouling when NF is applied as an advanced water treatment process of surface or ground water. In laboratory-scale experiments, we used two types of aluminum coagulant: poly-aluminum chloride ( $\mathrm{PACl}$ ) and alum and pretreated by in-line coagulation and ceramic MF. As an alternative coagulant, iron coagulant (ferric chloride) was also used. To clarify the effect of residual coagulants, groundwater that contained low organic matter was used as raw experimental water. To elucidate the effects of $\mathrm{SiO}_{2}$ on the $\mathrm{NF}$ membrane fouling, we added $\mathrm{SiO}_{2}$ to the raw water in some of the experiments. The results of the pilot scale experiment, in which PACl was used as a coagulant agent, were also presented and discussed.

\section{Experimental}

\subsection{Laboratory-scale experiment}

In the laboratory-scale experiment, Hokkaido University groundwater was used as raw experimental water. The average quality of this water was: DOC $0.5 \mathrm{mg} / \mathrm{L}, \mathrm{EC} 450$ $\mu \mathrm{S} / \mathrm{cm}, \mathrm{pH}$ 7.2, Na $29 \mathrm{mg} / \mathrm{L}, \mathrm{K} 9.6 \mathrm{mg} / \mathrm{L}$, Ca 50 mg/L, Mg $15 \mathrm{mg} / \mathrm{L}, \mathrm{Cl} 25 \mathrm{mg} / \mathrm{L}, \mathrm{SO}_{4} 40$ $\mathrm{mg} / \mathrm{L}$. Types of coagulants used were $\mathrm{PACl}\left(10 \% \mathrm{Al}_{2} \mathrm{O}_{3}\right.$, basicity $52 \%$, Japanese Industrial Standard (JIS) grade), alum (Aluminum Sulfate 14-18 Water, reagent grade, Wako Pure Chemicals, Osaka, Japan) or ferric chloride (Iron (III) Chloride Hexahydrate, reagent grade, Wake Pure Chemicals). The raw water was firstly treated with activated carbon cartridge filter to quench residual chlorine and then pretreated by in-line coagulation followed by MF. The MF filtrate ( $\mathrm{pH}$ 7.0-7.1) was then pumped at a rate of $1.5 \mathrm{~L} / \mathrm{h}$ to a flat sheet membrane test cell (filtration area $60 \mathrm{~cm}^{2}, \mathrm{C} 10-\mathrm{T}$, Nitto Denko Matex Corp., Tokyo, Japan; Fig. 1) that housed the NF membrane (UTC-60, nominal $\mathrm{NaCl}$ rejection 55\%, Toray Industries, Inc.). $\mathrm{NF}$ was performed at a filtration flux of 2.5 $\mathrm{cm} / \mathrm{h}$ and a water recovery rate of $10 \%$. The system flow is shown in Fig. 2 . We conducted nine experimental runs and their conditions are summarized in Table 1. In all experimental runs, the coagulant dose was set at $0.04 \mathrm{mM}(1.1 \mathrm{mg}-\mathrm{Al} / \mathrm{L}, 2.2 \mathrm{mg}-\mathrm{Fe} / \mathrm{L})$. MF was performed with a laboratory-use ceramic membrane (nominal pore size $0.1 \mu \mathrm{m}$, 
membrane area $0.4 \mathrm{~m}^{2}$, NGK Insulators, Nagoya, Japan) at very low filtration flux (0.83 $\mathrm{cm} / \mathrm{h}$ ), without periodic hydraulic backwashing; the MF membrane was replaced with a chemically cleaned membrane when the inlet pressure reached 0.05 MPa. After the NF experiments, spent NF membranes were cleaned with $2 \%$ citric acid, and the aluminum and iron concentrations in the citric acid drain were analyzed.

After five experimental runs with the laboratory-scale experimental setup, an automatic hydraulic backwash system was introduced to the MF step; the MF was performed at a normal filtration flux $(6.25 \mathrm{~cm} / \mathrm{h})$, and the MF membrane was hydraulically cleaned by backwash at a pressure of $500 \mathrm{kPa}$ for 10 seconds every $2 \mathrm{~h}$ [9]. MF permeate ( $\mathrm{pH}$ 6.8-7.0) was introduced to the NF membrane test cell at a filtration flux of $2.08 \mathrm{~cm} / \mathrm{h}$, which is slightly lower than the fluxes used for the previous experiments. Runs 6-9 were conducted with this system. Run 6 used PACl as a coagulant, and Run 7 used ferric chloride.

In the next two experimental runs (Runs 8 and 9), $\mathrm{SiO}_{2}$ was added to the chlorine-quenched groundwater before coagulation with $\mathrm{PACl}$ and $\mathrm{MF}$ pretreatment. By comparing these results with the results of Run 6 , in which the mean silicate

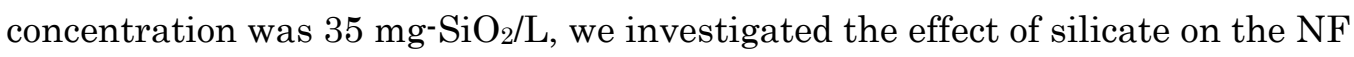
membrane fouling. Diluted sodium silicate was added so that the silicate concentration in the NF feed would be approximately $80 \mathrm{mg}-\mathrm{SiO}_{2} / \mathrm{L}$. Sodium silicate is a basic reagent, and thus the $\mathrm{pH}$ was adjusted to approximately 7 with hydrochloric acid. After Runs 6 , 8 , and 9 , the spent $\mathrm{NF}$ membranes were cleaned sequentially with $\mathrm{HCl}, \mathrm{NaOH}$, and citric acid; and then the aluminum, silicate, calcium, and potassium concentrations in the cleaning water were analyzed.

\subsection{Pilot MF-NF plant experiment}

The pilot plant received water at a rate of $24 \mathrm{~m}^{3} / \mathrm{h}$ from outlet of a sedimentation basin of Ishikawa Water Treatment Plant, Okinawa, Japan, after PACl (basicity 50\%, JIS grade) coagulation. In the pilot plant, MF (polyvinylidene fluoride membrane, nominal pore size $0.1 \mu \mathrm{m}$; Toray Industries, Inc., Tokyo, Japan) filtrates (pH 6.5-7.3) were transferred to the NF modules (nominal $\mathrm{NaCl}$ rejection 55\%; polyamide SU-610, Toray Industries, Inc.), which were operated at constant flux $(2.5 \mathrm{~cm} / \mathrm{h})$ and water recovery rate (95\%) by adjustment of the feed pressure. Average quality of MF filtered water was: TOC 0.9 mg/L, EC $185 \mu \mathrm{S} / \mathrm{cm}, \mathrm{Na} 19 \mathrm{mg} / \mathrm{L}, \mathrm{Ca} 11 \mathrm{mg} / \mathrm{L}, \mathrm{Cl} 27 \mathrm{mg} / \mathrm{L}, \mathrm{SO}_{4} 14$ $\mathrm{mg} / \mathrm{L}$, and residual $\mathrm{Al}$ was $0.03 \mathrm{mg} / \mathrm{L}$. The $15 \mathrm{NF}$ modules were placed in a multistage array ( $8,4,2$, and 1 modules in series), and the water recovery rate of each element was about $13 \%$. Details of the process configuration and operation are given elsewhere [8]. 
After 4.5 months of system operation, foulants on the NF membrane surface were collected by gentle scraping of the membrane deposits. The foulants were then dried, weighed, combusted for $30 \mathrm{~min}$ in a muffle furnace at $550{ }^{\circ} \mathrm{C}$, and then weighed again to obtain the mass of fixed solid. The recovered foulant was analyzed for $\mathrm{Al}, \mathrm{Ca}, \mathrm{Fe}, \mathrm{S}$, and Si.

\subsection{Analytical methods}

Aluminum and iron concentrations were measured by an inductively coupled plasma-mass spectrometer (ICP-MS; HP-4500; Agilent Technologies, Inc., Palo Alto, $\mathrm{CA}$, USA). Ion concentrations $\left(\mathrm{Na}^{+}, \mathrm{K}^{+}, \mathrm{Mg}^{+}, \mathrm{Ca}^{+}, \mathrm{Cl}^{-}, \mathrm{NO}_{3}{ }^{-}, \mathrm{SO}_{4}^{2-}\right)$ were measured by ion chromatograph (DX-120, Nippon Dionex K.K., Osaka, Japan). $\mathrm{SiO}_{2}$ was measure by molybdenum yellow colorimetric method. TOC and DOC were measured by TOC-5000A (Shimadzu Corporation, Kyoto, Japan) or Sievers 900 Laboratory TOC analyzer (GE Analytical Instruments, Boulder, CO, USA).

\section{Results and discussion}

\subsection{Laboratory-scale experiment pretreated with aluminum coagulants (Runs 1-3)}

Changes in NF membrane permeability over time in the laboratory-scale experiment with different aluminum coagulants (i.e., $\mathrm{PACl}$ and alum) are compared in Fig. 3. Because variation in the initial filtration flux of the pieces of NF membrane sheet used in the NF cross-flow cell was small, nanofilter permeability was evaluated in terms of the dimensionless standardized-filtration flux, which is the standardized flux at $1 \mathrm{MPa}$ and $25{ }^{\circ} \mathrm{C}$ divided by the standardized flux for pure water, as described by the following equations [10]:

$J=\frac{Q}{A} \cdot \frac{\alpha}{\Delta P}$

where $J$ is standardized filtration flux $[\mathrm{m} /(\mathrm{h} \cdot \mathrm{MPa})], Q$ is filtration rate $\left(\mathrm{m}^{3} / \mathrm{h}\right), \quad A$ is membrane surface area $\left(\mathrm{m}^{2}\right), \quad \alpha$ is a temperature compensation factor to $25^{\circ} \mathrm{C}$, and $\Delta P$ is transmembrane pressure (TMP) (MPa); and

$$
J^{*}=\frac{J}{J_{\mathrm{W}}}
$$

where $J^{*}$ is dimensionless standardized flux, and $J_{\mathrm{W}}$ is standardized filtration flux for pure water $[\mathrm{m} /(\mathrm{h} \cdot \mathrm{MPa})]$.

After 25 days of operation of the laboratory-scale experiment with $\mathrm{PACl}$ coagulant 
(Run 1) in which MF permeate (NF feed) had a mean aluminum concentration of 20 $\mu \mathrm{g} / \mathrm{L}$, the filtration flux decreased by about $15 \%$ (Fig. 3). In an experiment with alum coagulant (Run 2) in which NF feed contained aluminum at a mean concentration of 18 $\mu \mathrm{g} / \mathrm{L}$, the filtration flux again decreased by about $15 \%$. Lower mean aluminum concentration $(8.7 \mu \mathrm{g} / \mathrm{L})$ in NF feed was observed in another experiment with $\mathrm{PACl}$ coagulant (Run 3); we did not change any specific condition of coagulation and MF, and we could not elucidate the reason why we could achieve this lower residual aluminum concentration. In this Run 3, the NF membrane permeability did not change substantially. The percentage rejection of aluminum by NF was more than $85 \%$; most of the aluminum remaining after MF obviously could not permeate the NF membrane and thus had the potential to be deposited on the NF membrane, reducing membrane permeability. However, the aluminum concentrations in the NF retentates were only slightly higher than the concentrations in the corresponding NF feed; more than $98 \%$ of the aluminum fed to the NF was discharged with the NF retentate. Therefore, the high rejection ratio of aluminum did not produce a retentate that was highly concentrated in comparison with the feed and did not necessarily result in a high deposition rate on the NF membrane.

\subsection{Laboratory-scale experiment with iron coagulant pretreatment (Runs 4 and 5)}

Unlike Runs 1 and 2, Runs 4 and 5 did not show a large change in nanofilter permeability (Fig. 4). Mean iron concentrations in the NF feed after the ferric chloride coagulation and MF pretreatments in Runs 4 and 5 were 10 and $18 \mu \mathrm{g} / \mathrm{L}$, respectively, and the aluminum concentration in the NF feeds was less than $2 \mu \mathrm{g} / \mathrm{L}$. The percentage rejection of iron by NF was $60-90 \%$, which was not as high as that of aluminum. These results suggest that the concentration of residual aluminum after coagulation influenced NF fouling more strongly than did the residual iron concentration.

Table 2 summarizes the masses of aluminum and iron eluted from the spent NF membranes by citric acid. The membranes used in Runs 1 and 2, which showed larger permeability declines, contained more aluminum $\left(3.6\right.$ and $4.0 \mathrm{mg} / \mathrm{m}^{2}-$ membrane surface) than the others. The amount of iron eluted from the spent membranes was similar to the amount of aluminum (Table 2), but unlike the mass of aluminum, the mass of iron was not obviously correlated with membrane permeability decline (Figs. 3 and 4).

\subsection{Laboratory-scale experiment with backwashing in the MF step}




\subsubsection{Comparison of aluminum and iron coagulation (Runs 6 and 7)}

An automatic backwash was introduced to the MF step after Run 5, and this alteration permitted MF at a normal filtration flux. Under this altered condition, experimental runs with PACl coagulant (Run 6) and ferric chloride (Run 7) were performed. Nanofilter permeability declined during Run 6 (Fig. 5). In this run, the NF feed contained residual aluminum of $40 \mu \mathrm{g} / \mathrm{L}$ in average, and the membrane permeability declined by $25 \%$ after 60 days (1440 hours) of operation. The permeability declined at lower rates in this run than in Runs 1 and 2; this result was probably due to the fact that the filtration flux $(2.08 \mathrm{~cm} / \mathrm{h})$ was lower than in Runs 1 and $2(2.5 \mathrm{~cm} / \mathrm{h})$. In the experiment with ferric chloride (Run 7), no substantial decline in NF membrane permeability was observed; this result was the same as those for Runs 4 and 5.

\subsubsection{Effect of $\mathrm{SiO}_{2}$ addition (Runs 6, 8 and 9)}

When $\mathrm{SiO}_{2}$ was added to the water before the pretreatment by coagulation with $\mathrm{PACl}$ and MF (Runs 8 and 9), the NF membrane permeability declined at about double the speed observed for Run 6 (Fig. 6). The pH in Run 8 was not strictly controlled (the pH of the NF feed water fluctuated between 6.6 and 7.5). Aluminum is more soluble at alkaline $\mathrm{pH}$ than at neutral $\mathrm{pH}$ [11], and therefore the mean aluminum concentration in the NF feed was as high as $103 \mu \mathrm{g} / \mathrm{L}$. In Run 9, the $\mathrm{pH}$ was controlled more strictly (6.7-7.0 over the course of the run); nevertheless, the mean aluminum concentration was also rather high $(85 \mu \mathrm{g} / \mathrm{L})$ in this run. This higher residual aluminum may have been due to the effect of excess silicate. Lartiges et al. [12] reported that flocculation of colloidal silica with polymerized aluminum begins with the formation of negatively charged aluminosilicate sites. Duan and Gregory [13, 14] investigated the interaction of aluminum coagulants with silica and found that a small amount of dissolved silica can improve coagulation by affecting the charge-neutralizing behavior of hydrolyzed aluminum species, but silica coagulation is inhibited as the amount of silica is increased, as a result of the increasing negative charge of the particles.

To explore further the effect of a large amount of silicate on the faster decline of NF membrane permeability, we cleaned the spent membrane sequentially with $\mathrm{HCl}, \mathrm{NaOH}$, and citric acid after the experimental runs. Results after chemical cleaning with $\mathrm{HCl}$ are shown in Table 3; aluminum and silicate were recovered in molar ratios of 1:0.49 (Run 6), 1:1.52 (Run 8), and 1:1.78 (Run 9). These results suggest that aluminum and silicate were major inorganic foulants of the nanofilter.

We calculated the aluminum solubility diagram for the NF feed solution used in Runs 6, 8, and 9 (Fig. 7) with Geochemist's Workbench (ver. 6, RockWare, Inc., Golden, CO, 
USA). The major difference in the feed water quality of these runs was silicate concentration. The aluminum concentration in the NF feed water exceeded the upper solubility limit in the case of gibbsite $\left(\mathrm{Al}(\mathrm{OH})_{3}\right)$, pyrophyllite $\left(\mathrm{AlSi}_{2} \mathrm{O}_{5} \mathrm{OH}\right)$, and kaolinite $\left(\mathrm{Al}_{2} \mathrm{Si}_{2} \mathrm{O}_{5}(\mathrm{OH})_{4}\right)$, that is, an aluminum compound and two compounds containing both aluminum and silicate. Furthermore, changing the silicate concentration from 40 to 80 $\mathrm{mg}-\mathrm{SiO}_{2} / \mathrm{L}$ led to a large decrease in the solubility of pyrophyllite and kaolinite (from dotted line to solid line), although the solubility of gibbsite did not change. This result implies that more aluminum silicate compounds may have deposited on the NF membrane as the amount of silicate in the feed water increased. Therefore, the silicate concentration could play a major role in NF membrane fouling, even though the rejection rate of silicate itself was not high: the rejection percentages of silicate were only $10-20 \%$ in both the pilot plant and laboratory experiments.

Calcium was not detected on the spent membrane from Run 6 but was detected in Runs 8 and 9. In these runs, calcium was detected in the $\mathrm{NaOH}$ cleaning solution, which suggests that calcium fouled the NF membrane in combination with organic substances. In contrast, potassium was largely detected in the $\mathrm{HCl}$ and citric acid cleaning solutions. The molar ratios of aluminum to potassium in the $\mathrm{HCl}$ cleaning solution were 1:0.48 (Run 6), 1:1.02 (Run 8), and 1:0.70 (Run 9) (Table 3). The thermodynamic calculation (Geochemist's Workbench) also suggests that the aluminum concentration in the NF feed water was higher than the solubility of mordenite- $\mathrm{K}\left(\mathrm{K}_{2} \mathrm{Al}_{2} \mathrm{Si}_{10} \mathrm{O}_{24} \cdot 7 \mathrm{H}_{2} \mathrm{O}\right)$ (Fig. 7), and in some calculations, clinoptilolite- $\mathrm{K}\left(\mathrm{K}_{6} \mathrm{Al}_{6} \mathrm{Si}_{30} \mathrm{O}_{72}\right)$ also appeared as a candidate foulant (data not shown). These two minerals are siliceous zeolites [15, 16], and the chemical formulas of natural zeolites are very complicated; not only potassium but also other cations, including sodium, calcium, and magnesium, are incorporated into the zeolites because zeolites have ion-exchange properties [17]. The foulants in the other experiments were not analyzed for potassium (because we did not consider potassium as a potential foulant when the research started) and other cations except calcium; we therefore could not elucidate further the effects of these cations.

\subsection{Pilot MF-NF plant experiment}

The permeability of the first stage modules in the multistage array of nanofilters declined with operation time (Fig. 8). Although no severe membrane fouling was expected for the first-stage module, TMP doubled and the permeability (represented by standardized filtration flux at $25^{\circ} \mathrm{C}$ and $1 \mathrm{MPa}$ ) was reduced to $1 / 3$ the original permeability over 4.5 months of operation. The mean silt density index of the NF feed water was 2.25 (minimum 1.0, maximum 3.2), which suggests an absence of severe 
fouling by particulate matter. Gabelich et al. [18] recently reported that aluminum residuals, most notably from alum coagulation, cause colloidal fouling of RO membranes through interaction with the ambient silica to form aluminum silicate. They suggested that keeping the aluminum concentration at $<50 \mu \mathrm{g} / \mathrm{L}$ would result in stable RO membrane performance. The aluminum concentration in the NF influent of our experiment was below this suggested limit (mean $30 \mu \mathrm{g} / \mathrm{L}$, minimum $10 \mu \mathrm{g} / \mathrm{L}$, maximum $47 \mu \mathrm{g} / \mathrm{L})$.

Collection of the membrane deposits followed by combustion at $550{ }^{\circ} \mathrm{C}$, we recovered remaining foulants (regarded as ash) at a rate of $330 \mathrm{mg} / \mathrm{m}^{2}-$ membrane surface. We conducted elemental analysis of this ash for $\mathrm{Al}, \mathrm{Ca}, \mathrm{Fe}, \mathrm{S}, \mathrm{SiO}_{2}$ and their concentrations were $46,0.33,2.5,3.9$, and $30 \mathrm{mg} / \mathrm{m}^{2}$, respectively. This excessive accumulation of aluminum and silicate also suggests that aluminum residuals probably caused the membrane fouling by forming alumino-silicates or aluminum hydroxide.

\section{Conclusion}

Residual aluminum in the NF feed water greatly increased the decline of NF membrane permeability both in a pilot MF-NF plant experiment and in laboratory-scale MF-NF experiments when aluminum coagulants were used in the pretreatment process. On the contrary, there was no substantial decline in NF membrane permeability in the laboratory-scale experiments when ferric chloride was used as a coagulant. In the laboratory-scale experiments with aluminum coagulants, NF membrane permeability declined when the feed water contained residual aluminum at $18 \mu \mathrm{g} / \mathrm{L}$ or more, but not when the aluminum concentration was lower than about 9 $\mu \mathrm{g} / \mathrm{L}$. Therefore, the control of residual aluminum in the pretreatment processes of $\mathrm{NF}$ is crucial for mitigation of severe fouling of the NF membrane. The silicate concentration in the NF feed water also greatly increased NF membrane fouling, and other cations, especially potassium, may have been incorporated in the foulants in the form of zeolites.

\section{References}

[1] M. Siddiqui, G. Amy, J. Ryan and W. Odem, Membranes for the control of natural organic matter from surface waters, Water Res., 34 (13) (2000), 3355-3370.

[2] I. Mijatovic, M. Matosic, H. Cerneha, D. Bratulic, Removal of natural organic matter by ultrafiltration and nanofiltration for drinking water production, Desalination, 
169 (2004), 223-230.

[3] B. Van der Bruggen, J. Schaep, W. Maes, D. Wilms and C. Vandecasteele, Nanofiltration as a treatment method for the removal of pesticides from ground waters, Desalination, 117 (1998), 139-147.

[4] H. A. Kim, J. H. Choi and S. Takizawa, Comparison of initial filtration resistance by pretreatment processes in the nanofiltration for drinking water treatment, Sep. Purif. Technol., 56 (2007), 354-362.

[5] C. J. Gabelich, T. I. Yun, B. M. Coffey and I. H. Suffet, Effects of aluminum sulfate and ferric chloride coagulant residuals on polyamide membrane performance, Desalination, 150 (2002) 15-30.

[6] C. J. Gabelich, W. R. Chen, T. I. Yun, B. M. Coffey and I. H. Suffet, The role of dissolved aluminum in silica chemistry for membrane processes, Desalination, 180 (2005) 307-319.

[7] K. Ohno, E. Kadota, Y. Matsui, Y. Kondo, T. Matsushita and Y. Magara, Plant capacity affects some basic indices of treated water quality: multivariate statistical analysis of drinking water treatment plants in Japan, J. Water Supply: Res. T. AQUA, 58 (7) (2009), 476-487.

[8] T. Ohgai, Y. Oguchi, K. Ohno, T. Kamei, Y. Magara and M. Itoh, Development of evaluation methods to introduce a nanofiltration membrane process in drinking water treatment, Water Sci. Tech: Water Supply, 6 (2) (2006) 9-17.

[9] Y. Matsui, H. Hasegawa, K. Ohno, T. Matsushita, S. Mima, Y. Kawase and T. Aizawa, Effects of super-powdered activated carbon pretreatment on coagulation and trans-membrane pressure buildup during microfiltration, Water Res., 43 (20) (2009), $5160-5170$.

[10] M. Itoh and S. Kunikane, Evaluation method of nanofiltration membranes by semibatch experiment, J. Jpn. Water Works Assoc., 68 (11) (1999) 21-31 (in Japanese).

[11] MWH, Water Treatment: Principles and Design, 2nd ed., Jomn Wiley \& Sons, Inc., Hoboken, New Jersey (2005).

[12] B. S. Lartiges, J. Y. Bottero, L. S. Derrendinger, B. Humbert, P. Tekely and H. Suty, Flocculation of Colloidal Silica with Hydrolyzed Aluminum: An 27Al Solid State NMR Investigation, Langmuir, 13 (1997) 147-152.

[13] J. Duan and J. Gregory, Influence of soluble silica on coagulation by aluminium sulphate. Colloid Surface A, 107 (1996) 309-319.

[14] J. Gregory and J. Duan, The effect of dissolved silica on the action of hydrolysing metal coagulants, Water Sci. Tech., 38 (6) (1998) 113-120. 
[15] K. Itabashi, T. Fukushima and K. Igawa, Synthesis and characteristic properties of siliceous mordenite, Zeolites, 6 (1986) 30-34.

[16] D. Zhao, K. Cleare, C. Oliver, C. Ingram, D. Cook, R. Szostak and L. Kevan, Characteristics of the synthetic heulandite-clinoptilolite family of zeolites, Micropor. Mesopor. Mat., 21 (1998) 371-379.

[17] R. Y. Ning, Discussion of silica speciation, fouling, control and maximum reduction, Desalination, 151 (2002) 67-73.

[18] C. J. Gabelich, K. P. Ishida, F. W. Gerringer, R. Evangelista, M. Kalyan and I. H. Suffet, Control of residual aluminum from conventional treatment to improve reverse osmosis performance, Desalination, 190 (2006) 147-160. 
Table 1. Laboratory-scale experimental conditions and mean concentrations of residual coagulant in NF feed water

\begin{tabular}{|c|c|c|c|c|c|}
\hline Run & $\begin{array}{c}\text { Type of } \\
\text { Coagulant }\end{array}$ & $\begin{array}{c}\text { Automatic } \\
\text { backwash system } \\
\text { in MF and filtration } \\
\text { flux }(\mathrm{cm} / \mathrm{h})\end{array}$ & $\begin{array}{c}\mathrm{SiO}_{2} \text { was } \\
\text { added to be } \\
\sim 80 \mathrm{mg} / \mathrm{L} \text {. }\end{array}$ & $\begin{array}{l}\text { Mean } \\
\text { concentration of } \\
\text { residual coagulant } \\
\text { in NF feed water }\end{array}$ & $\begin{array}{l}\text { NF filtration } \\
\text { flux }(\mathrm{cm} / \mathrm{h})\end{array}$ \\
\hline 1 & $\mathrm{PACl}$ & \multirow{5}{*}{ No $(0.83)$} & & $20 \mu \mathrm{g}-\mathrm{Al} / \mathrm{L}$ & \multirow{5}{*}{2.5} \\
\hline 2 & Alum & & & $18 \mu \mathrm{g}-\mathrm{Al} / \mathrm{L}$ & \\
\hline 3 & $\mathrm{PACl}$ & & & $8.7 \mu \mathrm{g}-\mathrm{Al} / \mathrm{L}$ & \\
\hline 4 & $\mathrm{FeCl}_{3}$ & & & $10 \mu \mathrm{g}-\mathrm{Fe} / \mathrm{L}$ & \\
\hline 5 & $\mathrm{FeCl}_{3}$ & & & $18 \mu \mathrm{g}-\mathrm{Fe} / \mathrm{L}$ & \\
\hline 6 & $\mathrm{PACl}$ & \multirow{4}{*}{ Yes (6.25) } & & $40 \mu \mathrm{g}-\mathrm{Al} / \mathrm{L}$ & \multirow{4}{*}{2.08} \\
\hline 7 & $\mathrm{FeCl}_{3}$ & & & $8.6 \mu \mathrm{g}-\mathrm{Fe} / \mathrm{L}$ & \\
\hline 8 & $\mathrm{PACl}$ & & \multirow{2}{*}{ Yes } & $103 \mu \mathrm{g}-\mathrm{Al} / \mathrm{L}$ & \\
\hline 9 & $\mathrm{PACl}$ & & & $85 \mu \mathrm{g}-\mathrm{Al} / \mathrm{L}$ & \\
\hline
\end{tabular}

Table 2. NF membrane foulants in the laboratory-scale MF-NF experiment in Runs 1-5

\begin{tabular}{|c|c|c|c|}
\hline \multirow{2}{*}{} & \multirow{2}{*}{ Coagulant } & \multicolumn{2}{|c|}{ Foulant } \\
\cline { 3 - 4 } & & $\mathrm{Al}\left(\mathrm{mg} / \mathrm{m}^{2}\right)$ & $\mathrm{Fe}\left(\mathrm{mg} / \mathrm{m}^{2}\right)$ \\
\hline Run 1 & $\mathrm{PACl}$ & 3.6 & 2.5 \\
\hline Run 2 & Alum & 4.0 & 1.7 \\
\hline Run 3 & $\mathrm{PACl}$ & 1.8 & 2.1 \\
\hline Run 4 & $\mathrm{FeCl}_{3}$ & 0.2 & 3.3 \\
\hline Run 5 & $\mathrm{FeCl}_{3}$ & 1.2 & 1.8 \\
\hline
\end{tabular}


Table 3. Molar ratio of $\mathrm{Si}$ and $\mathrm{K}$ to $\mathrm{Al}$ recovered by cleaning with $\mathrm{HCl}$

\begin{tabular}{|c|c|c|c|}
\hline & $\begin{array}{c}\text { Mean Si concentration } \\
\text { in NF feed water } \\
\left(\mathrm{mg}^{-S i O} / \mathrm{L}\right)\end{array}$ & $\begin{array}{c}\mathrm{Si} / \mathrm{Al} \\
(\mathrm{mol} / \mathrm{mol})\end{array}$ & $\begin{array}{c}\mathrm{K} / \mathrm{Al} \\
(\mathrm{mol} / \mathrm{mol})\end{array}$ \\
\hline Run 6 & 35 & 0.49 & 0.48 \\
\hline Run 8 & 75 & 1.52 & 1.02 \\
\hline Run 9 & 77 & 1.78 & 0.70 \\
\hline
\end{tabular}




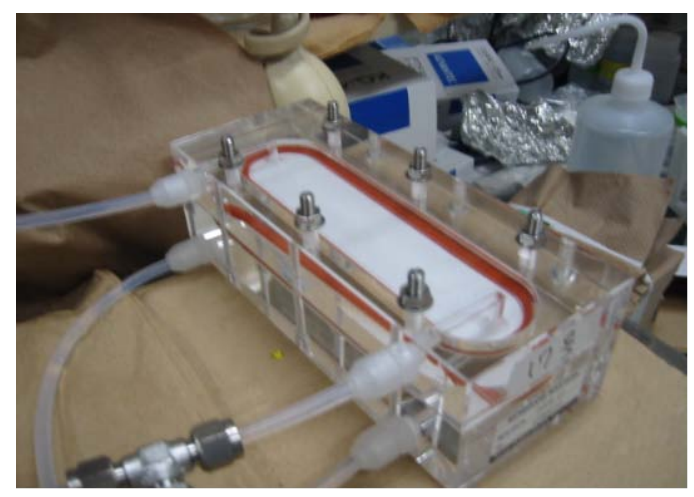

Fig. 1. Flat sheet membrane test cell

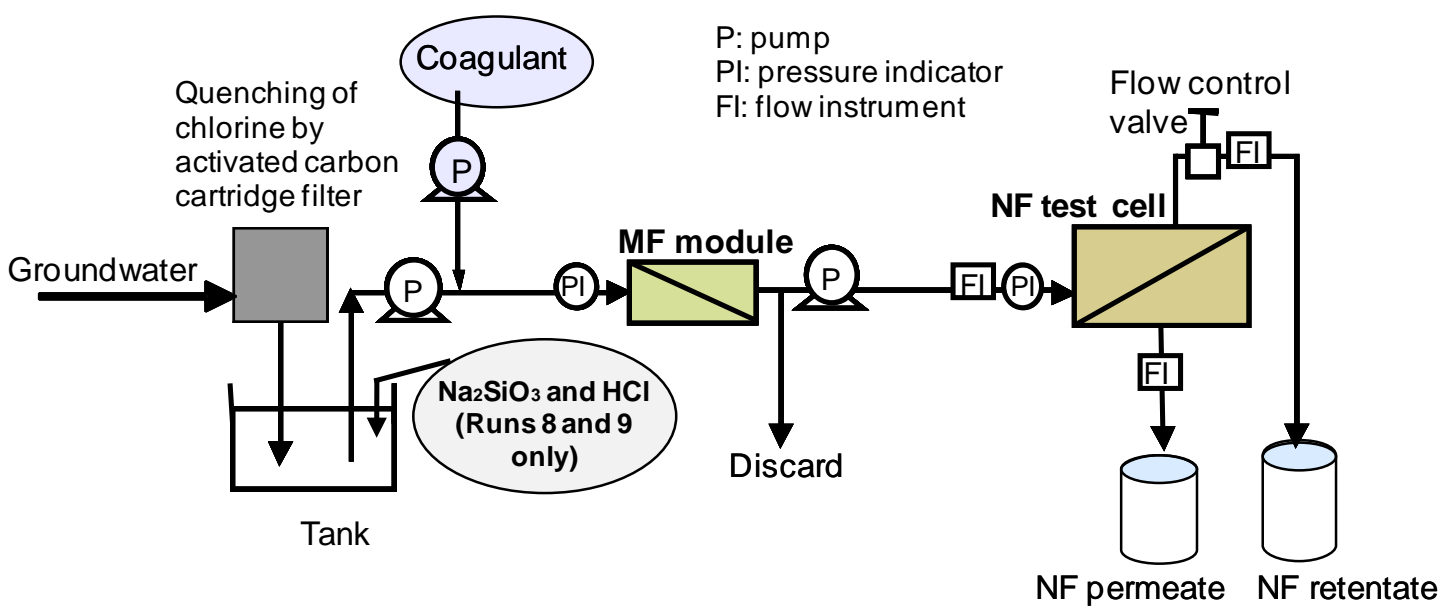

Fig. 2. Experimental setup for laboratory-scale MF-NF experiments 


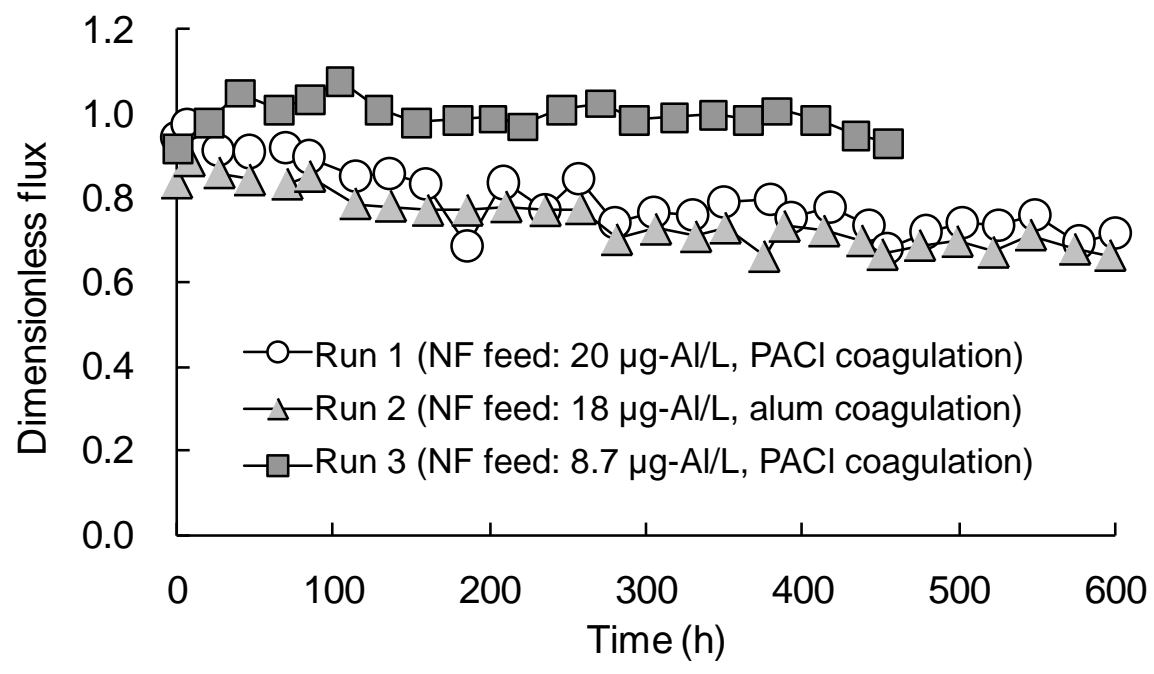

Fig. 3. Time dependence of dimensionless standardized flux (standardized flux/standardized flux for pure water) for NF after coagulation and MF in the laboratory-scale experiment (Runs 1-3).

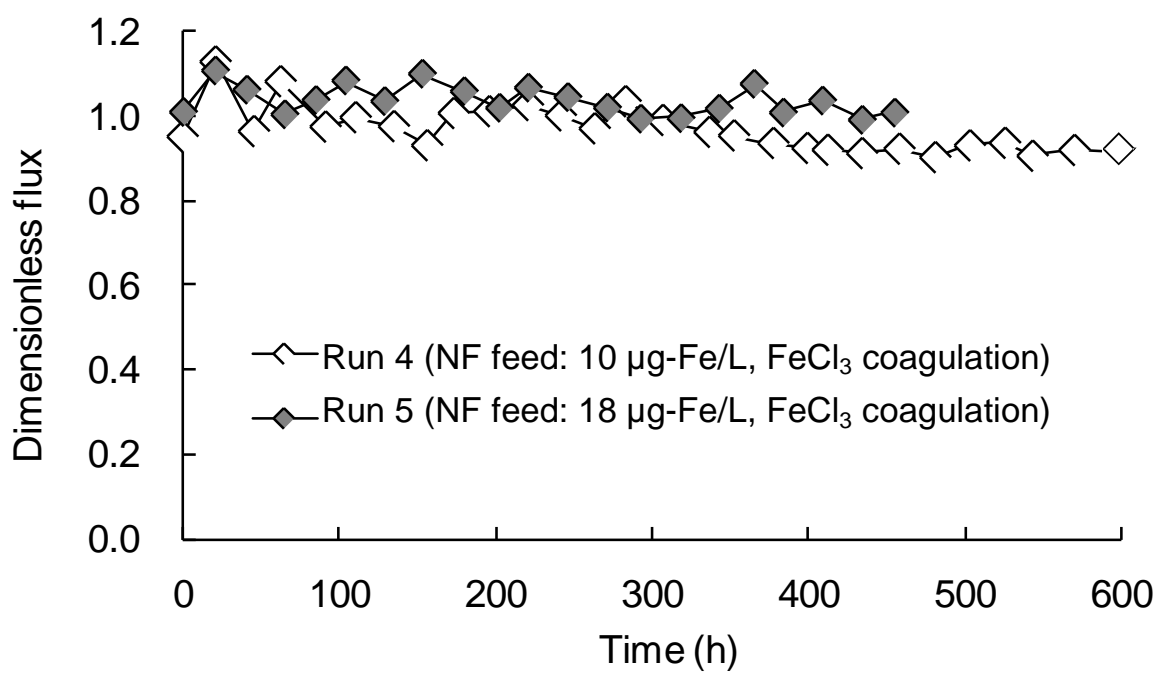

Fig. 4. Time dependence of dimensionless standardized flux (standardized flux/standardized flux for pure water) for NF after coagulation and MF in the laboratory-scale experiment (Runs 4 and 5). 


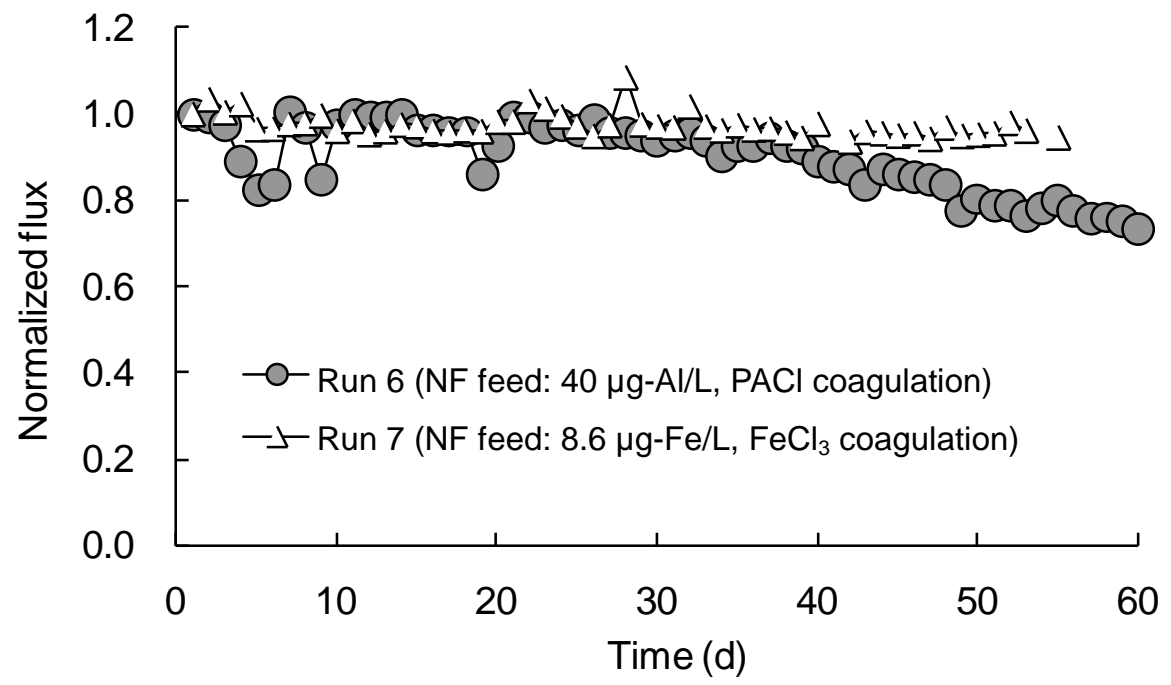

Fig. 5. Time dependence of normalized flux (standardized flux/first day standardized flux) for NF after coagulation and MF in the laboratory-scale experiment (Runs 6 and 7).

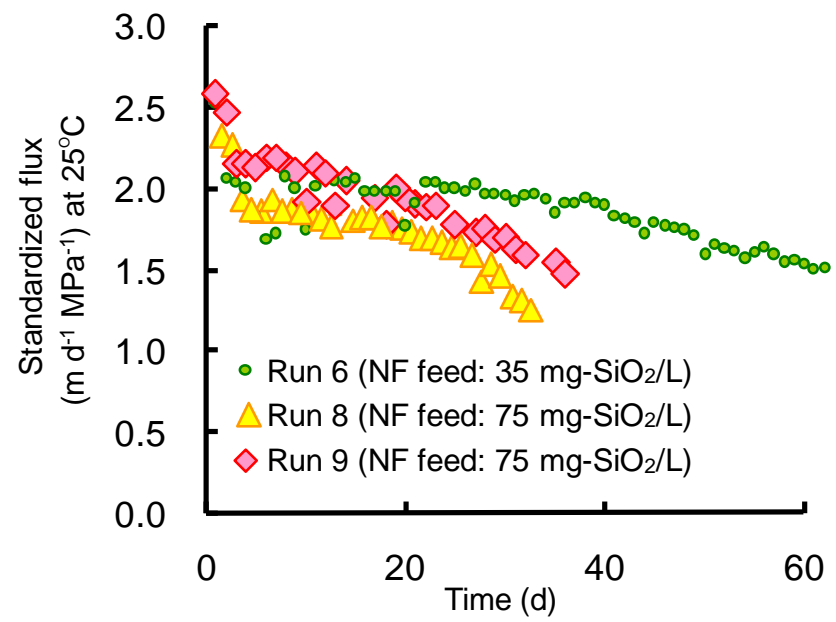

Fig. 6. Changes in standardized flux for NF after coagulation and MF in the laboratory-scale experiment (Runs 6, 8, and 9). 


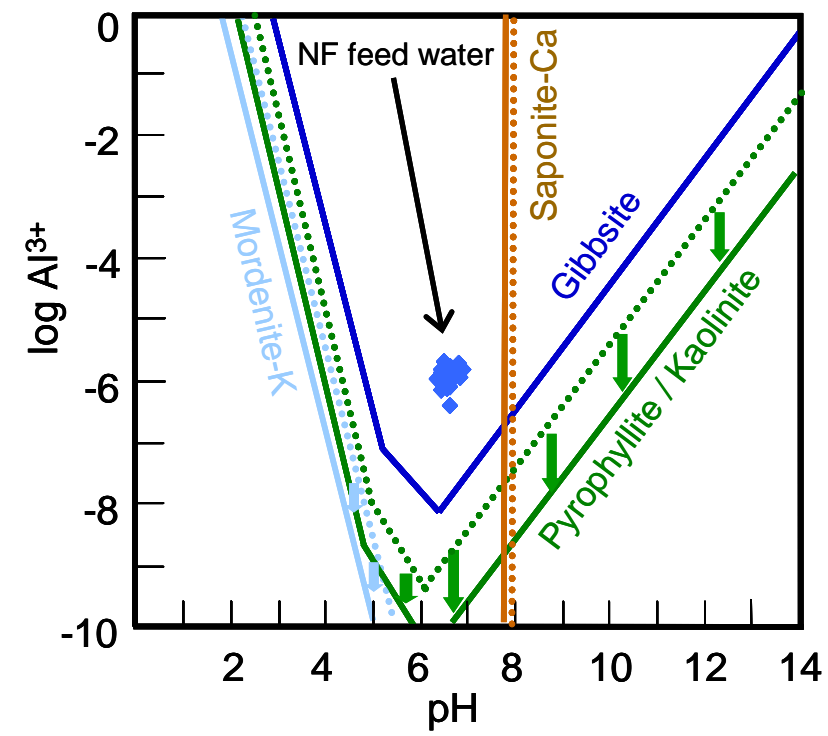

Fig. 7. Solubility diagram for aluminum at $25^{\circ} \mathrm{C}$ : dotted lines, solubility diagram for the NF feed solution in Run 6 (40 mg-SiO$/ 2 / L)$; solid lines, Runs 8 and 9 (80 mg-SiO$/ 2$ ).

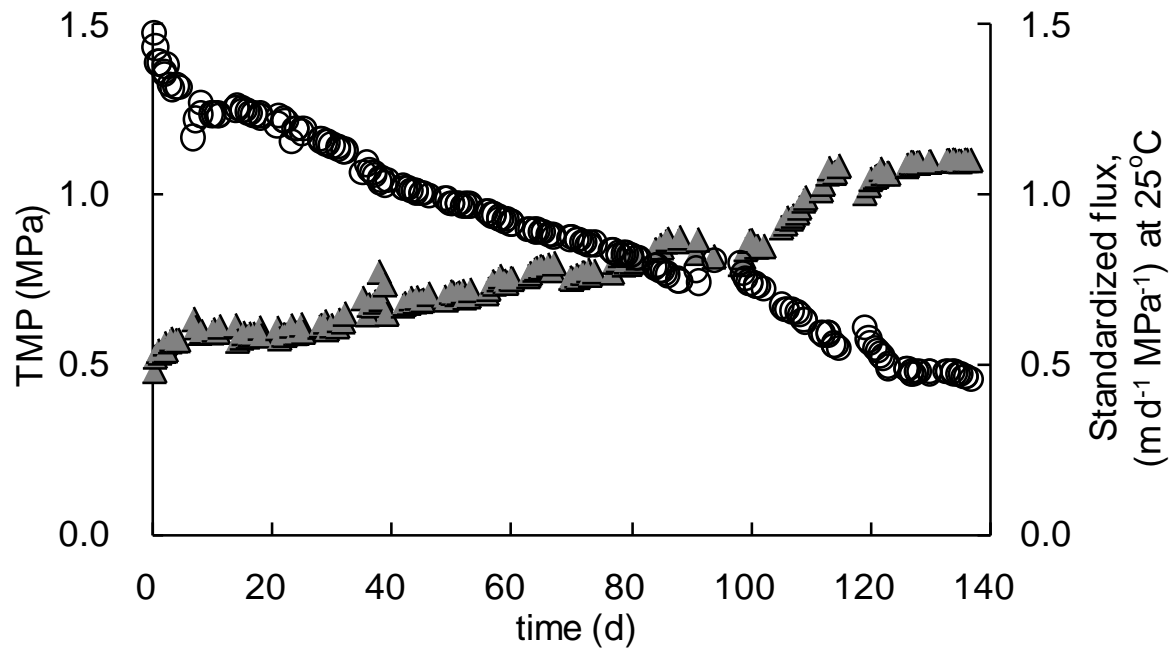

Fig. 8. Water permeability for the first stage of the multistage array in the NF pilot plant. Triangles, transmembrane pressure (TMP); circles, permeability represented by standardized filtration flux at $25^{\circ} \mathrm{C}$ and $1 \mathrm{MPa}$ of TMP. 